\title{
Variation in body size of Phanocerus clavicornis Sharp, 1882 (Coleoptera: Elmidae: Larainae) in Atlantic Rainforest streams in response to hydraulic disturbance
}

\author{
Segura, MO ${ }^{a,{ }^{*}}$, Siqueira, $T .{ }^{b}$ and Fonseca-Gessner, $A A .{ }^{c}$ \\ ${ }^{a}$ Departamento de Hidrobiologia, Universidade Federal de São Carlos, São Carlos, São Paulo, Brazil \\ ${ }^{b}$ Departamento de Ecologia, Instituto de Biociências, Universidade Estadual Paulista, Rio Claro, São Paulo, Brazil \\ ${ }^{c}$ Departamento de Hidrobiologia, Universidade Federal de São Carlos, São Carlos, São Paulo, Brazil \\ "e-mail:m_ottoboni@yahoo.com.br
}

Received July 31, 2012 - Accepted Ocdtober 23, 2012 - Distributed November 29, 2013

(With 3 figures)

\begin{abstract}
In this study, patterns of body size of Phanocerus clavicornis Sharp, 1882 (Coleoptera: Elmidae: Larainae) were investigated along a gradient of change in speed of flow conditions in streams of low order in the Atlantic Rainforest in southeastern Brazil. Specifically, the hypothesis that the distribution of $P$. clavicornis larvae vary in size in response to variations in the speed of flow in streams was tested. A Surber sampler was used to collect larvae from the streambed during two sampling periods, defined by the rain regime: August in the dry season and February in the rainy season. Possible differences in mean measured body size were tested by analysis of variance (ANOVA). The ANOVA result indicated for all measurements on the larvae collected in first-order streams (head width, prothoracic width and total body length), there were significant differences indicating a morphometric variation due to changing hydraulic conditions, the smallest larvae being associated with the period of greater rainfall. However, the larger streams $\left(3^{\text {rd }}\right.$ order $)$, where the rain events had less impact on the larval size, varied widely. The results of this study suggest that the interstitial space is important for the protection of the larvae from water flow, and that populations of $P$. clavicornis have high plasticity, a key feature for the occupation of unstable environments for this species. These results are important for an understanding of the life history and behavioural characteristics of the species, which allow them to persist in streams along a gradient of flow disturbance.
\end{abstract}

Keywords: aquatic insects, Brazil, flow refugia, habitat heterogeneity.

\section{Variação no tamanho corpóreo de Phanocerus clavicornis Sharp, 1882 (Coleoptera: Elmidae: Larainae) em córregos da Mata Atlântica sob perturbação hidráulica}

\section{Resumo}

Neste estudo, padrões de tamanho do corpo de Phanocerus clavicornis Sharp, 1882 (Coleoptera: Elmidae: Larainae) foram investigados ao longo de um gradiente de variação de velocidade da corrente em córregos de baixa ordem da Mata Atlântica. Especificamente, buscou-se testar a hipótese de que a distribuição de larvas de P. clavicornis com diferentes tamanhos corpóreos respondem às variações na velocidade da corrente em córregos. As coletas das larvas foram realizadas com um amostrador de Surber durante dois períodos amostrais, definidos pelo regime de chuvas: agosto - estação seca e fevereiro - estação chuvosa. Possíveis diferenças nas medidas de tamanho do corpo foram testadas através de uma análise de variância (ANOVA). Os resultados da ANOVA indicaram para todas as medidas das larvas coletadas nos córregos de primeira ordem (largura da cabeça, largura do protórax e comprimento total do corpo) encontramos diferenças significativas, indicando uma variação morfométrica com as mudanças das condições hidráulicas, onde as larvas menores foram associadas aos períodos de maior precipitação. No entanto, em córregos maiores $\left(3^{\mathrm{a}}\right.$ ordem), os eventos de chuva tiveram menor impacto no tamanho dos indivíduos, com a ocorrência de larvas com diferentes tamanhos. Os resultados deste estudo sugerem que os espaços intersticiais são importantes para a proteção das larvas contra a velocidade da corrente e que as populações de $P$. clavicornis possuem alta plasticidade, sendo uma característica fundamental para a ocupação desta espécie em ambientes instáveis. Esses resultados são importantes para a compreensão da história de vida e características comportamentais da espécie, que permitem persistir em córregos ao longo de gradiente de perturbação do fluxo.

Palavras-chave: insetos aquáticos, Brasil, refúgios, heterogeneidade ambiental. 


\section{Introduction}

In streams and rivers, hydraulic conditions can play a key role in the distribution of organisms, through direct effects, such as flooding and drag forces (Weissenberger et al., 1991; Collier et al., 1995) and indirect effects, such as those of stream flow on the substrate particles (Jowett et al., 1991) and food availability (Biggs and Hickey, 1994; Hart and Finelli, 1999). Variations in hydraulic conditions, especially current flow, can also disturb the fauna by removing or killing organisms (Townsend and Hildrew, 1994) and affecting reproduction rates, thus creating new opportunities for individuals to settle (Sousa, 1984). The impact of the resulting changes in resource availability and the substrate can be measured by the ecological responses of organisms (White and Pickett, 1985; Poff, 1992). For example, in temporally stable habitats species with long life spans and large body sizes can be found (Towsend and Hildrew, 1994).

The vulnerability of organisms to intense current flow can be reduced by morphological adaptations of the body or behavioural mechanisms such as the use of refugia (Statzner and Holm, 1989; Sedell et al., 1990; Sagnes et al., 2008). In streams, the irregular surface of inorganic substrates (Holomuzki and Biggs, 2003), leaves and wood debris (Palmer et al., 1996) often provide refuges from the current flow and enable survival during a disturbance (Lancaster et al., 2006). In adverse conditions, refuges can protect organisms that will later reoccupy the areas affected (Rempel, 1999). Research on the influence of current flow and the search for refugia and how they affect the functional attributes of invertebrates has recently become more prominent (e.g, Sibly and Calow, 1989; Sedella et al., 1990; Lancaster and Hildrew, 1993; Winterbottom et al., 1997; Franken et al., 2006). These studies suggest that the use of refugia plays a key role in determining the species composition and functional characteristics of benthic communities.

The event of high discharge in streams is known as the main disturbance affecting the structure of macroinvertebrate communities (Melo et al., 2003). In this study, we investigated patterns of body size of Phanocerus clavicornis Sharp, 1882 (Coleoptera: Elmidae: Larainae) along a gradient of change of stream flow. The effects of such disturbance can vary in relation to the body size of each organism: smaller individuals are more able to resist being washed away and/or survive under conditions associated with increased flow.

Phanocerus clavicornis was used as a model in our study because it is very frequently and abundantly found in streams of the Atlantic Rainforest in southeastern Brazil. Both larvae and adults of $P$. clavicornis are aquatic and found in the same environment (Brown, 1987; Spangler and Santiago-Fragoso, 1992) - in riffles, under rocks and accumulated leaves in shallow streams of clear and cold water (Spangler and Santiago-Fragoso, 1992). It is a widely distributed species, with records from southeastern Texas (USA) (Spangler and Santiago-Fragoso, 1992) to South America. In Brazil there are records of its occurrence in the Northern (Passos et al., 2010), Southern (Santa Catarina; Hinton, 1937) and Southeastern (São Paulo, Segura et al., 2011; Segura et al., 2012 and Rio de Janeiro, Passos et al., 2009) regions.

In this study, we assumed a direct relationship between the velocity of stream flow and seasonality, the flow being slower during the dry season than the rainy. We tested the hypothesis that Phanocerus clavicornis larvae have different body sizes in response to different current flow in streams of low order in the Atlantic Rainforest. Specifically, in the period of faster flow - the rainy season - the larvae of $P$. clavicornis would have a smaller body than in the period of slower flow - the dry season.

\section{Material and Methods}

\subsection{Study area and sampling}

The study was conducted in streams in the Parque Estadual de Campos do Jordão (PECJ), in Campos do Jordão, southeastern Brazil $\left(22^{\circ} 30^{\prime}-22^{\circ} 41^{\prime}\right.$ S by $45^{\circ} 27^{\prime}$ $45^{\circ} 31^{\prime} \mathrm{W}$ ) (Figure 1). The Park, covering 8,385 ha, includes areas of Dense and Mixed Rainforest and highaltitude fields of grass. The average elevation is $1,650 \mathrm{~m}$ and the highest point is situated at $1,900 \mathrm{~m}$ above sea level (Seibert, 1975) (Figure 1). The climate is humid and cool with concentrated rain between the months of October and February and less frequent rain between March and September (Seibert, 1975). Figure 2 shows the monthly variation of rainfall in the Park area during the study period, clearly slowing the seasonality described above.

In PECJ there is a dense network of tributary streams, which drain into the Sapucaí-Guaçu River basin. The

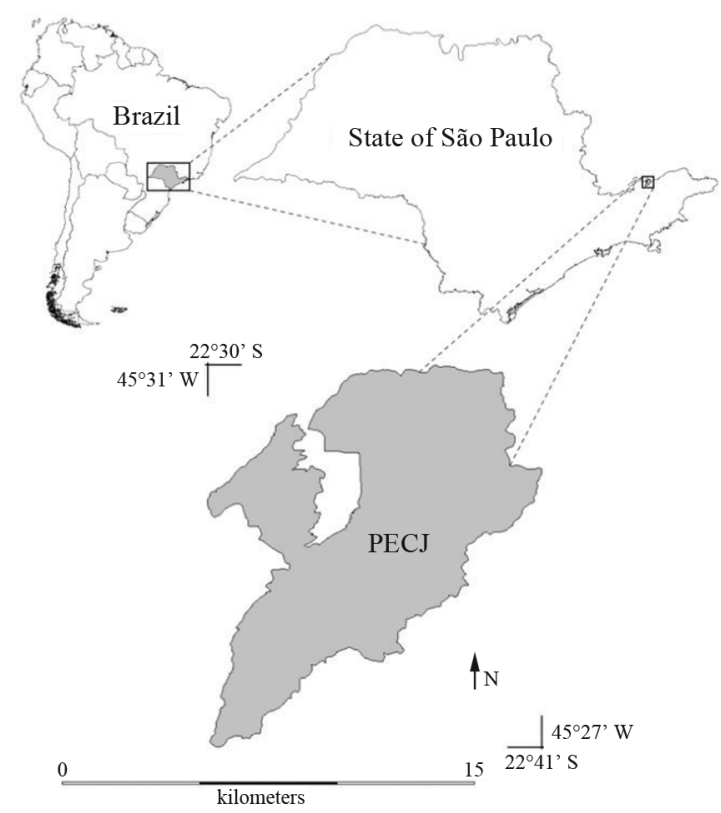

Figure 1 - Geographic location of Parque Estadual de Campos do Jordão, São Paulo state, Brazil. 


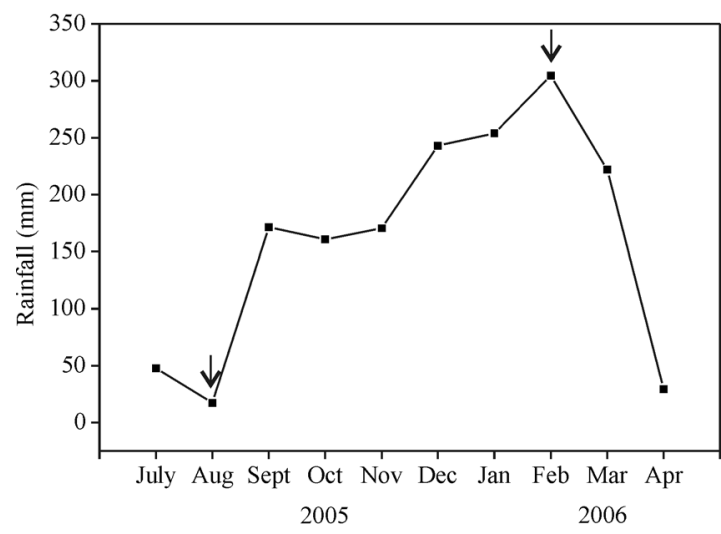

Figure 2 - Variation in rainfall from July/2005 to April/2006 in the Parque Estadual de Campos do Jordão, São Paulo, Brazil. The arrows indicate the periods of sampling. Data provided by Weather Station No. 83,714, $7^{\text {th }}$ District of Meteorology of the Ministry of Agriculture, Parque Estadual de Campos do Jordão, SP, Brazil.

streams have mountain characteristics, with a streambed of gravel, stones, sand and fine sediments and cold, clean and oxygenated water.

Phanocerus clavicornis larvae were collected in six low order streams $\left(1^{\text {st }}\right.$ and $\left.3^{\text {rd }}\right)$ in areas of riffles with accumulation of leaves: three streams of first order (average width: $1.31 \pm 0.46 \mathrm{~m}$ and average depth: $0.12 \pm$ $0.08 \mathrm{~m}$ ) and three streams of third order (average width: $2.85 \pm 0.677 \mathrm{~m}$ and average depth: $0.26 \pm 0.051 \mathrm{~m}$ ).

Sampling occurred on two occasions, in the month of August, in the period of low rainfall (47.2 mm), and February, during the rainy season $(253.8 \mathrm{~mm})$ (Figure 2). In each stream five samples were collected from leaves in riffles, totalling 30 samples per period. The material was sampled with a Surber collector of reduced area (area of $0.0361 \mathrm{~m}^{2}, 0.25 \mathrm{~mm}$ mesh). The material collected was fixed in $4 \%$ formaldehyde on site and transported to the laboratory, where it was washed on a mesh of $0.25 \mathrm{~mm}$, sorted under a stereomicroscope and preserved in $80 \%$ ethanol. The material is deposited in the collection of the Aquatic Insect Laboratory of the Universidade Federal de São Carlos (Brazil).

\subsection{Body size}

For each larva, linear measurements of the greatest width of head (including eyes), prothoracic width (near the line of insertion of mesothoracic) and total body length were recorded (Figure 3). Measurements were taken through a magnifying glass coupled to a Leica DFC 295 digital camera. Thirty individuals per sample were measured.

\subsection{Statistical analysis}

Possible differences in body size were tested by applying analysis of (ANOVA). We first tested the normality of the data by the Shapiro-Wilk test and homogeneity of variance by Levene's test. Since the data did not show

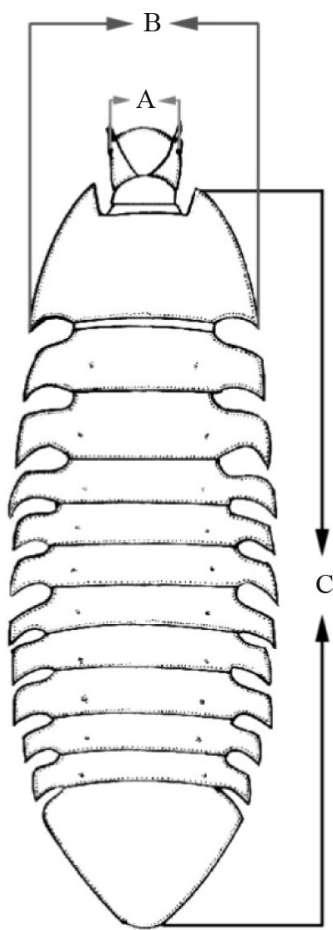

Figure 3 - Phanocerus clavicornis Sharp, 1882 larva in dorsal view, showing the structures measured for analysis. (A) Head width, (B) width of the prothoracic and (C) body length. Illustration: Adapted from Passos et al. (2007).

a normal distribution - not even after logarithmic transformation - we used a nonparametric ANOVA. P-values were obtained by permutation tests ( 999 permutations), following the procedure proposed by Pierre Legendre (available at: http://www.bio.umontreal.ca/legendre/) and implemented in program $\mathrm{R}$ ( $\mathrm{R}$ Development Core Team, 2010).

First we used a two-way ANOVA to test the existence of interaction between the factors (a) current flow in the two climatic periods (dry and rainy) and (b) length of streams ( $1^{\text {st }}$ order and $3^{\text {rd }}$ order $)$. If a significant interaction was found, we would analyse the effect of current flow factor on the body size separately in streams of the first and third orders, by one-way ANOVA. For all tests, we used a statistical significance of $\mathrm{p} \leq 0.05$.

\section{Results}

We found differences in all measurements of larvae (i.e., body size, width of the head and base of prothoracic) with respect to the stream current flow factor, but not with respect to the stream order factor (Table 1). As a significant interaction between factors was found, we decided to analyse the effect of the flow rate factor in streams of the first and third orders separately, by oneway ANOVA. This interaction between factors indicates that the effect of flow rate on size depends on the size of 
Table 1 - Two-way Anova results for (a) total body size, (b) head length and (c) width of the prothoracic of Phanocerus clavicornis Sharp, 1882 larvae found in first and third-order streams, in rainy and dry periods.

\begin{tabular}{lcccc}
\hline & Df & MS & F & p \\
\hline (a) body size & & & & \\
Period & 1 & 4.242 & 24.288 & 0.001 \\
Stream order & 1 & 0.26 & 1.492 & 0.203 \\
Interaction & 1 & 0.834 & 4.777 & 0.026 \\
Residual & 341 & 0.174 & & \\
(b) head & & & & \\
Period & 1 & 1.432 & 17.503 & 0.001 \\
Stream order & 1 & 0.134 & 1.643 & 0.194 \\
Interaction & 1 & 0.249 & 3.055 & 0.095 \\
Residual & 341 & 0.081 & & \\
(c) prothoracic & & & & \\
Period & 1 & 5.861 & 35.88 & 0.001 \\
Stream order & 1 & 0.21 & 1.288 & 0.242 \\
Interaction & 1 & 0.746 & 4.568 & 0.03 \\
Residual & 341 & 0.163 & & \\
\hline
\end{tabular}

Note: df: degrees of freedom; MS: mean squared deviation.

the stream, i.e., there may be an effect in streams of a given order, but not in streams of another order.

In the one-way ANOVA, we also found differences in all measurements of the larvae (size of body, head and base of prothoracic) in first-order streams, while in the third-order streams, differences were found only in prothoracic width measurements, between the periods of low and high flow (Table 2). In first-order streams, the larvae were smaller in the season of high flow than those collected in the period of low flow. In third-order streams, the $P$. clavicornis larvae were of equal size in the two periods.

The average size for all measurements was smaller in high rainfall and larger during low rainfall, but sizes varied greatly in both periods.

\section{Discussion}

In streams, current flow fluctuations are a source of disturbance to benthic communities. Thus, a local or temporary increased flow can disrupt the bed, which can have negative effects, ending the permanence of benthic organisms, causing immediate death or an unfavorable drift downstream (Collier et al., 1995; Lancaster and Beyea, 1997). Our results suggest that larvae of $P$. clavicornis have different body sizes in response to changes in current flow in the low-order streams of the Atlantic Rainforest.

This study was designed to assess the effects of natural hydraulic disturbance on larvae of aquatic Coleoptera.
Table 2 - One-way Anova results for effect of season on (a) total body size, (b) head length and (c) width of the prothoracic of larvae from first and third-order streams.

\begin{tabular}{lcccc}
\hline & Df & MS & F & p \\
\hline $\begin{array}{l}\text { First order stream } \\
\text { (a) body size }\end{array}$ & & & & \\
all factors & 1 & 4.35 & 25.397 & 0.001 \\
Residual & 168 & 28.781 & & \\
(b) head & & & & \\
all factors & 1 & 1.416 & 17.201 & 0.001 \\
Residual & 168 & 13.839 & & \\
(c) prothoracic & & & & \\
all factors & 1 & 5.311 & 31.226 & 0.001 \\
Residual & 168 & 0.17 & & \\
$\begin{array}{l}\text { Third order stream } \\
\text { (a) body size }\end{array}$ & & & & \\
all factors & 1 & 0.667 & 3.751 & 0.058 \\
$\begin{array}{l}\text { Residual } \\
\text { (b) head }\end{array}$ & 173 & 30.775 & & \\
all factors & 1 & 0.246 & 3.034 & 0.093 \\
Residual & 173 & 14.061 & & \\
(c) prothoracic & & & & \\
all factors & 1 & 1.231 & 7.854 & 0.008 \\
Residual & 173 & 27.13 & & \\
\hline
\end{tabular}

Note: df: degrees of freedom; MS: mean squared deviation.

Our initial hypothesis that rainfall events would influence the body size of the larvae of $P$. clavicornis in first and third-order streams has not been completely confirmed. Analysis of the results showed that rainfall events can influence the size of larvae of $P$. clavicornis in smaller streams $\left(1^{\text {st }}\right.$ order $)$. For all the measurements on the larvae (head width, prothoracic width and total body length), significant differences were found, indicating a morphometric variation caused by changing hydraulic conditions, in which the smallest larvae were associated with the period of greater rainfall. Similar results were reported in a previous study in a river in Australia, where, after a major flood, the invertebrates were smaller (Thomson, 2002). Benthic invertebrates depend on the characteristics of the substrate for the availability of protected places under rocks and in cracks to prevent hydraulic stress (Lancaster and Hildrew, 1993). Reduced body size is favoured in adverse hydraulic conditions because smaller larvae can penetrate substrates of low porosity, in small interstitial spaces that serve as refugia against current displacement (Townsend and Thompson, 2007). In adverse conditions, organisms in these shelters are more likely to survive and later re-colonise the affected areas. The active search by macroinvertebrates for 
shelter during high-flow events was confirmed in observations made during simulated floods in tanks (Holomuzki and Biggs, 2000). In this simulation, immature Ephemeroptera and Trichoptera made small movements between the layers of the substrate as the flow increased.

On the other hand, Merigoux and Dolédec (2004) analysed streams in southern France, and obtained the opposite results to those reported here. Larger body sizes were found predominantly under extreme hydraulic stress. They argued that morphological and behavioural characteristics such as the ability to cling to the substrate may be enhanced, according to the size of the individual thus, overcoming the disadvantage due to larger size. Our results suggest that in third-order streams there may be a balance between a better use of refugia by smaller larvae and greater ability to settle on the substrate by larger larvae. In these streams we observed the largest ranges of body size with both lowest and highest limits in periods of higher water flow.

Our initial hypothesis was not confirmed for the larger streams ( $3^{\text {rd }}$ order), where the rain events had less impact on the larval size, which varied widely. These results can be explained by the greater stability of larger streams. The size of the stream is undoubtedly one of the fundamental factors determining the structure of lotic ecosystems (Vannote et al., 1980). In natural systems, the fluctuations of the channel decrease as the order of the river and spatial heterogeneity increase, resulting in a more stable community in the larger rivers (Harrel and Dorris, 1968; Allan and Castilho, 2007). This suggests that in lotic systems, areas of greater spatial heterogeneity are less disturbed by temporal variations (Townsend and Hildrew, 1994) and can provide not only a greater number of habitats, but also a greater number of refugia (Sedell, 1990; Rempel, 1999). Also, Matthaei and Townsend (2000) report that bigger individuals of Hydora sp. (Elmidae: Larainae) were found in more stable areas in rivers in New Zealand. The results of this study validate the idea that larger shelters in larger streams are qualitatively different from those in small streams (Rempel, 1999).

\section{Conclusion}

Our results suggest that populations of Phanocerus clavicornis have great phenotypic plasticity, a key feature for the occupation of unstable environments by this species. This is probably one explanation for its success in the streams and rivers of the Atlantic Rainforest, where variations in the velocity of the current flow during larval development may reduce the fitness of individuals and the population size. These results are important for an understanding of the life history and behavioural characteristics of the species, which allow them to persist in streams along a gradient of flow disturbance. Also, there was evidence of overlapping $P$. clavicornis generations, since we found a wide variation in body size during the periods studied, with mature and young larvae in the same period.

\section{Acknowledgments}

We are grateful to Dr. Marcia Regina Spies and Dr. Ana Emília Siegloch for helping to collect specimens, to Dr. Luciana Bueno dos Reis Fernandes for helping with some photos and Dr. Neusa Hamada for technical support (Pronex- CNPq/FAPEAM). We also thank Francisco Valente Neto and Gustavo Rincon Mazão for valuable comments during the elaboration of this study. The authors wish to thank the São Paulo State Research Foundation (FAPESP) and the Coordinating Office for the Advancement of Higher Education (Capes) for financial support.

\section{References}

ALLAN, JD. and CASTILHO, MM., 2007. Stream ecology: Structure and function of running waters. 2nd edition. Dordrecht: Kluger Academic Publishers.

BIGGS, BF. and HICKEY, CW., 1994. Periphyton response to hydraulic gradient in a regulated river in New Zealand. Freshwater Biology, vol. 32, p. 49-59.

BROWN, HP., 1987. Biology of Riffle Beetles. Annual Review of Entomology, vol. 32, p. 253-273.

COLLIER, KJ., CROKER, GF., HICKEY, CW., QUINN, JM. and SMITH BS., 1995. Effects of hydraulic conditions and larval size on the microdistribution of Hydrobiosidae (Trichoptera) in two New Zealand rivers. New Zealand Journal of Marine and Freshwater Research, vol. 29, p. 439-451.

Development Core Team, 2010. R: A language and environment for statistical computing. Vienna: R Foundation for Statistical Computing. Available from: http://www.rproject.org.

FRANKEN, RJM., GARDENIERS, JJP., BEIJER, JAJ. and PEETERS, ETHM., 2006. Effects of interstitial refugia and current velocity on growth of the amphipod Gammarus pulex Linnaeus. Journal of the North American Benthological Society, vol. 25, no. 3, p. 656-663.

HARREL, RC. and DORRIS, TC., 1968. Stream Order, Morphometry, Physico-Chemical conditions and community structure of benthic macroinvertebrates in an intermittent stream system. American Midland Naturalist, vol. 80 , no. 1 , p. $220-251$.

HART, DD. and FINELLI, CM., 1999. Physical-biological coupling in streams. The pervasive effects of flow on benthic organisms. Annual Reviews of Ecology and Systematics, vol. 30, p. 363-395.

HINTON, HE., 1937. Notes on some Brazilian Potamophilinae and Elminae (Coleoptera, Dryopidae). Entomologist's Monthly Magazine, vol. 73, p. 95-100.

HOLOMUZKI, JR. and BIGGS, BJF., 2000. Taxon-Specific Responses to High-Flow Disturbance in Streams: Implications for Population Persistence. Journal of the North American Benthological Society, vol. 19, no. 4, p. 670679.

HOLOMUZKI, JR. and BIGGS, BJF., 2003. Sediment texture mediates high-flow effects on lotic macroinvertebrates. Journal of the North American Benthological Society, vol. 22, p. 542-553.

JOWETT, IG., RICHARDSON, J., BIGGS, BJF., HICKEY, CW. and QUINN, JM., 1991. Microhabitat preferences of benthic invertebrates and the development of generalized Deleatidium spp. Habitat suitability curves, applied to 
four New Zealand rivers. New Zealand Journal of Marine and Freshwater Research, vol. 25, p.187-200.

LANCASTER, J. and BELYEA, LR., 1997. Nested hierarchies and scale-dependence of mechanisms of flow refugium use. Journal of the North American Benthological Society, vol. 16, p. 221-238.

LANCASTER, J., BÉLANGER-BUFFIN, T., REID, I. and RICE, S., 2006. Flow and substratum- mediated movement by a stream insect. Freshwater Biology, vol. 51, p. 1053-1069.

MATTHAEI, C. and TOWNSEND, CR., 2000. Long-term effects of local disturbance history on mobile stream invertebrates. Oecologia, vol. 125, p. 119-126.

MERIGOUX, S. and DOLEDEC, S., 2004. Hydraulic requirements of stream communities: a case study on invertebrates. Freshwater Biology, vol. 49, p. 600-613.

MELO, AS., NIYOGI, DK., MATTHAEI, CD. and TOWSEND, CR., 2003. Resistance, resilience. and patchiness of invertebrate assemblages in native tussock and pasture streams in New Zealand after a hydrological disturbance. Canadian Journal of Fisheries an Aquatic Sciences, vol. 60, p. 731-739.

PALMER, MA., ARENSBURGER, AP., MARTIN, AP. and DENMAN, DW., 1996. Disturbance and patch-specific responses: the interactive effects of woody debris dams on lotic invertebrates. Oecologia, vol. 105, p. 247-257.

PASSOS, MIS., NESSIMIAN, JL. and FERREIRA-JR, N., 2007. Chaves para identificação dos gêneros de Elmidae (Coleoptera) ocorrentes no Estado do Rio de Janeiro, Brasil. Revista Brasileira de Entomologia, vol. 51, no. 1, p. $42-53$.

PASSOS, MIS., SAMPAIO, BHL., NESSIMIAN, JL. and FERREIRA-JR, N., 2009. Elmidae (Insecta: Coleptera) do Estado do Rio de Janeiro: lista de espécies e novos registros. Arquivos do Museu Nacional, vol. 67, no. 3-4, p. 377-382.

PASSOS, MIS., FERNANDES, AS., HAMADA, N. and NESSIMIAN, JL., 2010. Insecta, Coleoptera, Elmidae, Amazon region. Check List, vol. 6, p. 538-545.

POFF, NL., 1992. Why disturbances can be predictable: a perspective on the definition of disturbance in streams. Journal of the North American Benthological Society, vol. 11, p. 86-92.

REMPEL, LL., RICHARDSON, JS. and HEALEY, MC., 1999. Flow refugia for benthic macroinvertebrates during flooding of a large river. Journal of the North American Benthological Society, vol. 18, no. 1, p. 34-48.

SAGNES, P., MERIGOUX, S. and PÈRU, N., 2008. Hydraulic habitat use with respect to body size of aquatic insect larvae: Case of six species from a French Mediterranean type stream. Limnologica, vol. 38, p. 23-33.

SEDELL, JR., REEVES, GH., HAUER, FR., STANFORD, JA. and HAWKINS, CP ., 1990. Role of refugia in recovery from disturbances: Modern fragmented and disconnected river systems. Environmental Management, vol. 14, p. 711-724.
SEGURA, MO., FONSECA-GESSNER, AA., SPIES, MR. and SIEGLOCH, AE., 2012. Water Beetles in mountainous regions in Southeastern Brazil. Brazilian Journal of Biology, vol. 72, no.2, p. 311-321.

SEGURA, MO., VALENTE-NETO, F. and FONSECA-GESSNER, AA., 2011. Elmidae (Coleoptera, Byrrhoidea) larvae in the state of São Paulo, Brazil: Identification key, new records and distribution. Zookeys, vol. 151, p. 53-74.

SEIBERT, P., 1975. Plano de Manejo do Parque Estadual de Campos do Jordão. Boletim Técnico do Instituto Florestal, vol. 19, p. 1-153.

SIBLY, RM. and CALOW, P., 1989. A life-cycle theory of responses to stress. Biological Journal of the Linean Society, vol. 37, p. 101-116.

SOUSA, WP., 1984. The role of disturbance in natural communities. Annual Review of Ecology, Evolution and Systematics, vol. 15, p. 353-391.

SPANGLER, PJ. and SANTIAGO-FRAGOSO, S., 1992. The aquatic beetle subfamily Larainae (Coleoptera: Elmidae) in Mexico, Central America and the West Indies. Smithsonian Contributions to Zoology, vol. 528, p. 1-74.

STATZNER, B. and HOLM, TF., 1989. Morphological adaptation of shape to flow: microcurrents around lotic macroinvertebrates with known Reynolds numbers at quasinatural flow conditions. Oecologia, vol. 78, p. 145-157.

THOMSON, JR., 2002. The effects of hydrological disturbance on the densities of macroinvertebrate predators and their prey in a coastal stream. Freshwater Biology, vol. 47, p. 1333-1351.

TOWNSEND, CR. and HILDREW, AG., 1994. Species traits in relation to a habitat templet for river systems. Freshwater Biology, vol. 31, p. 265-275.

TOWNSEND, CR. and THOMPSON, RM., 2007. Body size in streams: macroinvertebrate community size composition along natural and human-induced environmental gradients. In HILDREW, AG., RAFFAELLI, DG. and EDMONDS-BROWN, R. (Eds.). Body size: The Structure and Function of Aquatic Ecosystems. Cambridge: Cambridge University Press. p.78-97.

VANNOTE, RL., MINSHALL, GW., CUMMINS, KW., SEDELL, JR. and CUSHING, CE., 1980. The river continuum concept. Canadian Journal of Fisheries an Aquatic Sciences, vol. 37, p.130-137.

WEISSENBERGER, J., SPATZ HC., EMANS, A. and SCHOERBEL, J., 1991. Measurement of lift and drag forces in the range experienced by benthic arthropods at velocities below $1.2 \mathrm{~m} / \mathrm{s}$. Freshwater Biology, vol. 25, p. 21-31.

WHITE, PS. and PICKETT, STA., 1985. Natural disturbance and patch dynamics: an introduction. In PICKETT, STA. and WHITE, PS. (Eds.). The Ecology of Natural Disturbance and Patch Dynamics. Orlando: Academic Press. p. 3-13.

WINTERBOTTOM, JH., ORTON, SE., HILDREW, AG. and LANCASTER, J., 1997. Field experiments on flow refugia in streams. Freshwater Biology, vol. 37, p. 569-580. 